\title{
Non-contiguous finished genome sequence of Ornithobacterium rhinotracheale strain H06-030791
}

\author{
Emilie S Zehr $^{1 *}$, Darrell O Bayles ${ }^{2}$, William D Boatwright ${ }^{1}$, Louisa B Tabatabai ${ }^{1,3}$ and Karen B Register ${ }^{1}$
}

\begin{abstract}
The Gram-negative, pleomorphic, rod-shaped bacterium Ornithobacterium rhinotracheale is a cause of pneumonia and airsacculitis in poultry. It is a member of the family Flavobacteriaceae of the phylum "Bacteroidetes". O. rhinotracheale strain H06-030791 was isolated from the lung of a turkey in North Carolina in 2006. Its genome consists of a circular chromosome of 2,319,034 bp in length with a total of 2243 protein-coding genes and nine RNA genes. Genome sequences are available for two additional strains of O. rhinotracheale, isolated in 1988 and 1995, the latter described in a companion genome report in this issue of SIGS. The genome sequence of O. rhinotracheale strain H06-030791, a more contemporary isolate, will be of value in establishing core and pan-genomes for $O$. rhinotracheale and elucidating its evolutionary history.
\end{abstract}

Keywords: Ornithobacterium rhinotracheale, Respiratory disease, Poultry, Genome sequence

\section{Introduction}

Ornithobacterium rhinotracheale has been implicated as a cause of respiratory disease in domesticated fowl since at least 1981 [1]. Initially characterized as a phenotypically unusual bacterium of uncertain identity [2], Vandamme et al. [3] further characterized and named O. rhinotracheale in 1994. O. rhinotracheale is a global pathogen in farmed turkeys and chickens as well as a variety of other domesticated and wild birds, including chukar partridges, geese, ducks, guinea fowl, ostriches, gulls, pheasants, partridges, pigeons, quail, rooks, and falcons $[4,5]$. Based on the reactivity of heat-extracted antigens with monospecific antisera, 18 serotypes of $O$. rhinotracheale have been defined, designated as A through $\mathrm{R}[1,4]$, although not all isolates are typeable. The most common clinical signs of disease related to O. rhinotracheale are tracheitis, pneumonia, airsacculitis, sinusitis, and pericarditis [1,4]. The bacterium is responsible for substantial economic losses to the poultry industry worldwide, resulting from decreased egg production, reduced eggshell quality and hatchability, reduced weight gain, increased mortality, and increased condemnation rates [6-9]. Whole-cell bacterin and live, attenuated vaccines

\footnotetext{
* Correspondence: emilie.zehr@ars.usda.gov

${ }^{1}$ Ruminant Diseases and Immunology Research Unit, U. S. Department of Agriculture, Agricultural Research Service, National Animal Disease Center, Ames, IA, USA

Full list of author information is available at the end of the article
}

have met with variable success, likely due to the lack of cross-protection against heterologous serotypes. Recent studies have identified antigens that appear to provide cross-protective immunity when formulated as a recombinant, multi-component subunit vaccine [10].

O. rhinotracheale strain H06-030791 was isolated in 2006 from the lung of a turkey in North Carolina and subsequently determined to be serotype A in the laboratory of Dr. K. V. Nagaraja at the University of Minnesota, St. Paul, MN. Further study revealed that growth of $O$. rhinotracheale strain H06-030791 in vitro is unaffected by the presence of an iron chelator [11] a phenotype not shared by most of the other field isolates tested. Whether or how this attribute plays a role in disease is not yet clear. Although O. rhinotracheale has generally been considered nonhemolytic on blood agar, Tabatabai et al. [12] documented strong $\beta$-hemolytic activity of O. rhinotracheale strain H06-030791 and suggested that a hemolysin-like protein may function as a virulence factor. Here we present a description of the noncontiguous finished genome of $O$. rhinotracheale strain H06-030791 and its annotation. This isolate (alias P5932) was provided to the National Animal Disease Center by the University of Minnesota and is available from the National Animal Disease Center Biological Agent Archive. 


\section{Organism information}

\section{Classification and features}

The genus Ornithobacterium belongs to the class Flavobacteriia and is in the family Flavobacteriaceae [13] (Table 1). O. rhinotracheale is the sole species within the genus. Phylogenetic analysis based on $16 \mathrm{~S}$ ribosomal RNA of O. rhinotracheale and other genera within the Flavobacteriaceae family is shown in
Figure 1. The $16 \mathrm{~S}$ rRNA sequences of O. rhinotracheale strain H06-030791 and the type strain, LMG 9086, share $99.9 \%$ nucleotide sequence identity. Three rRNA loci were found in the genome of $O$. rhinotracheale strain H06-030791. All O. rhinotracheale strains in Figure 1 were isolated from turkeys, with the exception of strain LMG 11554, which was cultured from a rook.

Table 1 Classification and general features of 0 . rhinotracheale strain H06-030791 in accordance with the MIGS recommendations [14]

\begin{tabular}{|c|c|c|c|}
\hline MIGS ID & Property & Term & Evidence code $^{\mathrm{a}}$ \\
\hline & Current classification & Domain "Bacteria" & TAS $[15,16]$ \\
\hline & & Phylum "Bacteroidetes" & $\operatorname{TAS}[17,18]$ \\
\hline & & Class "Flavobacteriia" & $\operatorname{TAS}[19,20]$ \\
\hline & & Order Flavobacteriales & TAS $[21,22]$ \\
\hline & & Family Flavobacteriaceae & TAS [23-25] \\
\hline & & Genus Ornithobacterium & TAS $[26,27]$ \\
\hline & & Species rhinotracheale & $\operatorname{TAS}[26,27]$ \\
\hline \multirow[t]{8}{*}{ MIGS-7 } & Subspecific genetic lineage (strain) & Strain H06-030791 & TAS [11] \\
\hline & & Serotype A & IDA \\
\hline & Gram stain & Negative & $\operatorname{TAS}[1,4]$ \\
\hline & Cell shape & Pleomorphic rod & $\operatorname{TAS}[1,4]$ \\
\hline & Motility & Nonmotile & $\operatorname{TAS}[1,4]$ \\
\hline & Sporulation & Non-sporulating & TAS $[1,4]$ \\
\hline & Temperature range & Mesophile $\left(30^{\circ} \mathrm{C}-42^{\circ} \mathrm{C}\right)$ & $\operatorname{TAS}[1,4]$ \\
\hline & Optimum temperature & $37^{\circ} \mathrm{C}$ & TAS $[1,4]$ \\
\hline \multirow[t]{2}{*}{ MIGS-6.2 } & $\mathrm{pH}$ range; Optimum & 7.2-7.6 (BHI); 7.4 & TAS [1], IDA \\
\hline & Carbon source & Saccharolytic (glucose) & TAS [4] \\
\hline MIGS-6 & Habitat & Respiratory tract of birds worldwide & TAS $[1,4]$ \\
\hline MIGS-6.3 & Salinity & Growth in BHI broth, (0.75\% salts) & TAS [1], IDA \\
\hline \multirow[t]{2}{*}{ MIGS-22 } & Oxygen requirement & Microaerophilic, anaerobic, or aerobic & $\operatorname{TAS}[1,4]$ \\
\hline & Energy metabolism & Chemoorganotroph & TAS [4] \\
\hline MIGS-15 & Biotic relationship & Parasitic & TAS [4] \\
\hline MIGS-14 & Pathogenicity & Pneumonia, airsacculitis, tracheitis, pericarditis & TAS $[1,4]$ \\
\hline MIGS-16 & Specific host & Poultry & $\operatorname{TAS}[1,4]$ \\
\hline \multirow[t]{2}{*}{ MIGS-18 } & Health status of host & Symptomatic & TAS [11] \\
\hline & Biosafety level & $2 t$ & TAS [28] \\
\hline MIGS-19 & Trophic level & Chemoheterotroph & TAS [4] \\
\hline MIGS-23.1 & Isolation & Turkey lung & TAS [11] \\
\hline MIGS-4 & Geographic location & North Carolina, USA & TAS [11] \\
\hline MIGS-5 & Time of sample collection & 2006 & NAS \\
\hline MIGS-4.1 & Latitude & Not reported & \\
\hline MIGS-4.2 & Longitude & Not reported & \\
\hline MIGS-4.3 & Depth & Not reported & \\
\hline MIGS-4.4 & Altitude & Not reported & \\
\hline
\end{tabular}

${ }^{a}$ Evidence codes - IDA: Inferred from Direct Assay by Dr. K. V. Nagaraja, University of Minnesota, St. Paul, MN; TAS: Traceable Author Statement (i.e., a direct report exists in the literature); NAS: Non-traceable Author Statement (i.e., not directly observed for the living, isolated sample, but based on a generally accepted property for the species, or anecdotal evidence). Evidence codes are from the Gene Ontology project [29]. 


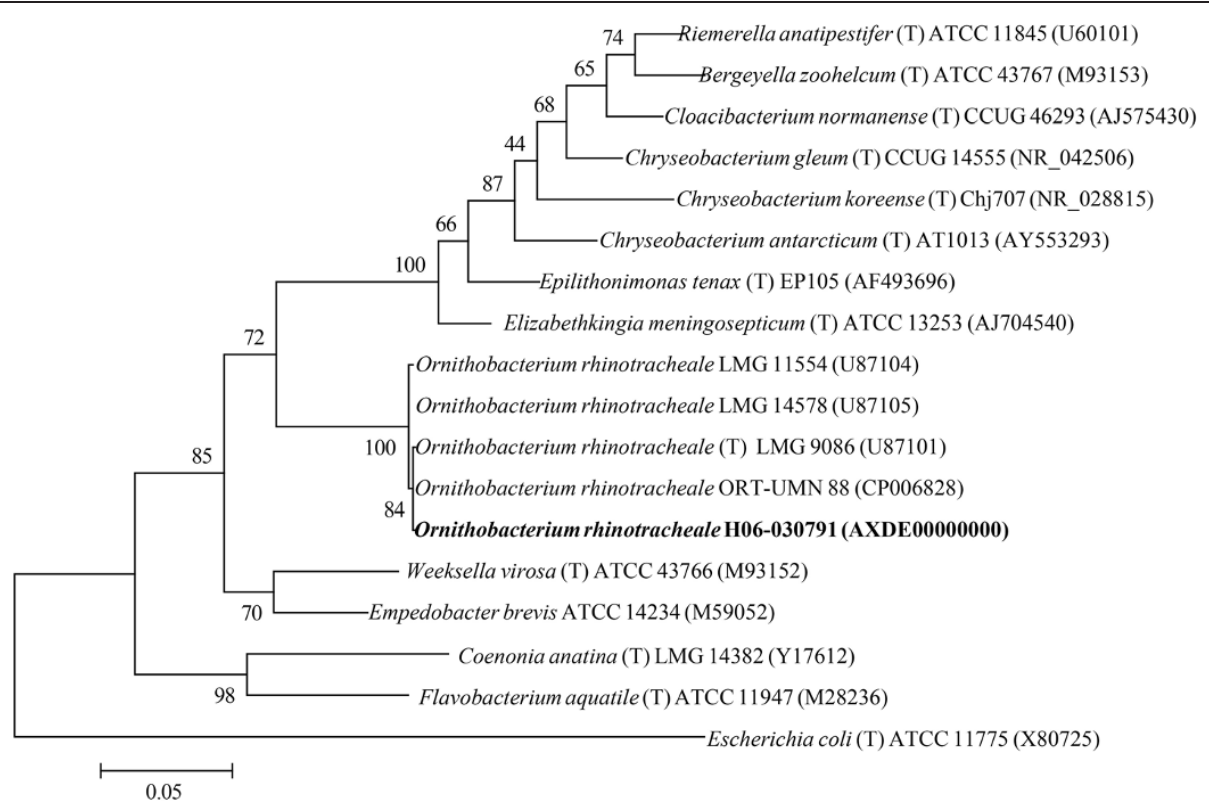

Figure 1 Phylogenetic tree based on 16S rRNA showing the position of O. rhinotracheale strain H06-030791 (highlighted in bold) in relation to other $O$. rhinotracheale isolates for which sequence is available and to the type strains (T) of closely related species and genera within the family Flavobacteriaceae. Escherichia coli (a member of the Enterobacteriaceae family) was included as an outgroup. An internal region of the $16 \mathrm{~S}$ RNA gene (1251 bp with no gap-containing sites) was aligned using CLUSTALW and phylogenetic inferences were obtained using the maximum likelihood method and the Jukes-Cantor model within MEGA version 5.10 software [37]. Numbers at the nodes are percentages of bootstrap values obtained by repeating the analysis 1000 times to generate a majority consensus tree. GenBank accession numbers for the DNA sequences used are shown in parentheses. The scale bar represents $5 \%$ substitution per nucleotide position.

O. rhinotracheale strain H06-030791 is a Gram-negative, pleomorphic rod, when grown in broth medium, ranging from 1.57-2.19 $\mu \mathrm{m}$ (mean, $1.93 \mu \mathrm{m}$ ) in length and $0.42-0.64 \mu \mathrm{m}$ (mean, $0 . .48 \mu \mathrm{m}$ ) in width (Figure 2). The bacterium is nonmotile and microaerophilic, and prefers a $7.5 \% \mathrm{CO}_{2}$ humidified atmosphere from $30^{\circ} \mathrm{C}$ to $42^{\circ} \mathrm{C}$ for growth. Colonies are approximately $1 \mathrm{~mm}$ in diameter and yellowish in color after $48 \mathrm{~h}$ incubation at $37^{\circ} \mathrm{C}$ on blood agar. Although O. rhinotracheale type strain LMG 9086 is nonhemolytic [3], O. rhinotracheale strain H06-030791 is $\beta$-hemolytic on 5\% sheep blood agar [12].

Biochemical tests for O. rhinotracheale strains can yield variable results [1]. After seven days of incubation at $37^{\circ} \mathrm{C}, \mathrm{O}$. rhinotracheale strain $\mathrm{H06}-030791$ is weakly acidic on a triple sugar iron agar slant and does not produce hydrogen sulfide or gas. Dextrose is weakly fermented with or without the addition of $2 \%$ chicken serum, while galactose and lactose are weakly fermented only with the addition of $2 \%$ chicken serum. Sucrose, sorbitol, xylose, and mannitol are not fermented with or without the addition of $2 \%$ chicken serum. The isolate is lysine decarboxylase positive, ornithine decarboxylase negative, and urease negative.

\section{Genome sequencing and annotation} Genome project history

Genome sequences are currently available for only two additional strains of $O$. rhinotracheale, the type strain LMG 9086 (isolated in 1988) and strain ORT-UMN 88

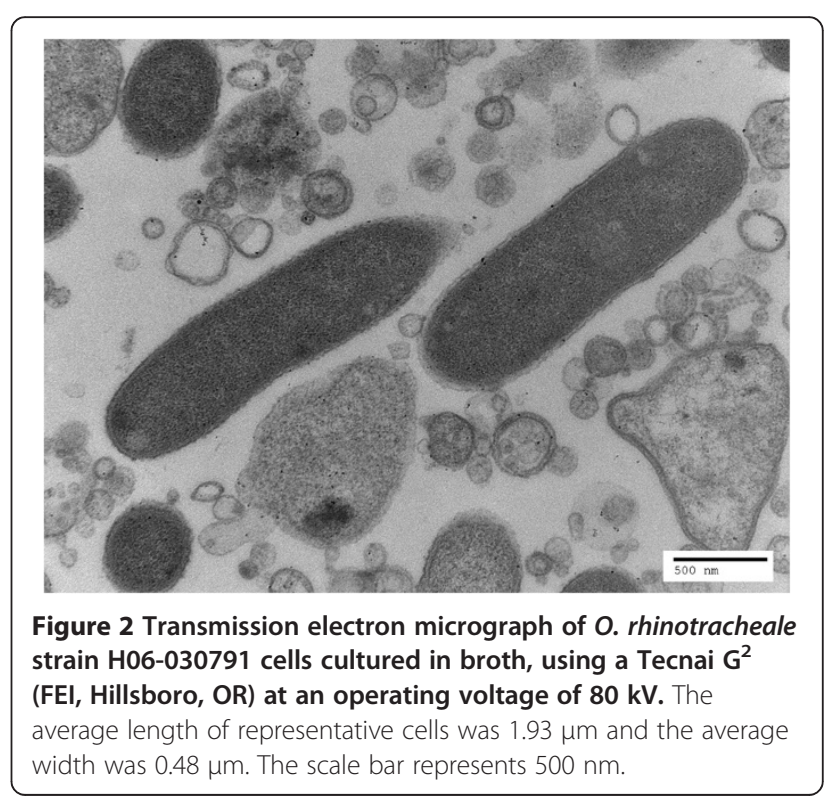


(isolated in 1995; see companion report in this issue of SIGS). O. rhinotracheale strain H06-030791 was selected for sequencing to provide a basis for comparative analysis of contemporary versus historical isolates. Additionally, $O$. rhinotracheale strain H06-030791 possesses phenotypic traits unique from those of $O$. rhinotracheale strain LMG 9086 and O. rhinotracheale strain ORT-UMN 88 [11,12] that may permit a more accurate representation of the core and pan-genomes of $O$. rhinotracheale. The Whole Genome Shotgun project and non-contiguous finished genome sequence of $O$. rhinotracheale strain H06-030791 has been deposited in DDBJ/EMBL/GenBank under accession no. AXDE00000000. Sequencing, finishing, and final annotation were performed at the DNA Facility of Iowa State University and the National Animal Disease Center, Ames IA. A summary of the project information is given in Table 2.

\section{Growth conditions and DNA isolation}

A clonal population of O. rhinotracheale strain H06030791 was derived from a single colony serially passaged three times and archived at $-80^{\circ} \mathrm{C}$ for future analysis. The bacterium was grown on $5 \%$ sheep blood agar plates (Becton, Dickinson and Company, Sparks, $\mathrm{MD}$ ) incubated for $48 \mathrm{~h}$ at $37^{\circ} \mathrm{C}$ with $7.5 \% \mathrm{CO}_{2}$ and $15 \%$ humidity. Colonies were used to inoculate $5 \mathrm{ml}$ of brain heart infusion broth in a snap-cap tube which was incubated at $37^{\circ} \mathrm{C}$ for $24 \mathrm{~h}$ with rotation at $100 \mathrm{rpm}$. Twenty $\mathrm{ml}$ of these BHI cultures were inoculated into $100 \mathrm{ml}$ of fresh BHI in a 250-ml flask and incubated at $37^{\circ} \mathrm{C}$ for $48 \mathrm{~h}$ with rotation at $75 \mathrm{rpm}$ (final $\mathrm{OD}_{600}=$ 0.278). An aliquot was plated on $5 \%$ sheep blood agar to confirm purity and $20 \mathrm{ml}$ was removed for DNA preparation. Cells were pelleted successively into one 2-ml centrifuge tube at $16,000 \times$ g. Genomic DNA was isolated using the Wizard Genomic DNA Purification Kit (Promega
Table 3 Genome statistics of 0 . rhinotracheale strain H06-030791

\begin{tabular}{lrr}
\hline Attribute & \multicolumn{2}{c}{ Genome (total) } \\
\cline { 2 - 3 } & \multicolumn{1}{c}{ Value } & \% of total \\
\hline Genome size (bp) & $2,319,034$ & $100.00 \%$ \\
DNA coding (bp) & $2,100,363$ & $90.57 \%$ \\
DNA G + C (bp) & 800,726 & $34.53 \%$ \\
Total genes & 2300 & $100.00 \%$ \\
Protein-coding genes & 2243 & $97.52 \%$ \\
RNA genes & 9 & $0.39 \%$ \\
rRNA operons & 3 & \\
tRNA genes & 42 & $1.83 \%$ \\
Pseudo genes & 6 & $0.27 \%$ \\
Genes with function prediction & 1058 & $47.17 \%$ \\
Genes assigned to COGs & 1384 & $61.70 \%$ \\
Genes assigned Pfam domains & 1487 & $66.30 \%$ \\
Genes with signal peptides & 254 & $11.32 \%$ \\
Genes with transmembrane helices & 471 & $21.00 \%$ \\
CRISPR repeats & 1 & \\
\hline
\end{tabular}

The total is based on either the size of the genome in base pairs or the total number of protein coding genes in the annotated genome.

Corporation, Madison, WI) with the following modifications: the cell pellet was resuspended in $480 \mu \mathrm{l}$ of $200 \mathrm{mM}$ EDTA, $60 \mu \mathrm{l}$ of $10 \mathrm{mg} / \mathrm{ml}$ lysozyme, and $60 \mu \mathrm{l}$ of double distilled water prior to lysis, then $10 \mu \mathrm{l}$ of $10 \mathrm{mg} / \mathrm{ml}$ RNase solution was added to the cell lysate. The precipitated genomic DNA was rehydrated at $65^{\circ} \mathrm{C}$ for $1 \mathrm{~h}$ in $10 \mathrm{mM}$ Tris- $\mathrm{HCl}, \mathrm{pH} 8.5$, evaluated on a $6 \%$ agarose gel to verify the lack of low molecular weight fragments, and quantified using the Quant-iT PicoGreen ds DNA Assay Kit (Invitrogen, Carlsbad, CA).

Table 2 Project information of O. rhinotracheale strain H06-030791

\begin{tabular}{lll}
\hline MIGS ID & Property & Term \\
\hline MIGS-31 & Finishing quality & Non-contiguous finished \\
MIGS-28 & Libraries used & Three genomic libraries: two shotgun libraries, one mate-pair library (8 kb insert size) \\
MIGS-29 & Sequencing platforms & Illumina GA II, Roche GS FLX Titanium, Sanger \\
MIGS-31.2 & Fold coverage & $48 \times(26 \times$ Roche FLX, 23× Illumina); final SEQuel error correction with 100x IIlumina \\
MIGS-30 & Assemblers & MIRA v3.4.0, Roche gsAssembler v2.8 \\
MIGS-32 & Gene calling method & GeneMarkS + (NCBI PGAP) \\
& GenBank ID & AXDE00000000 \\
& GenBank Date of Release & September 22, 2014 \\
& GOLD ID & Gi0071045 \\
& NCBI project ID & 219465 \\
& Project relevance & Poultry respiratory pathogen \\
MIGS-13 & Source material identifier & H06-030791 \\
\hline
\end{tabular}




\section{Genome sequencing and assembly}

A scaffolded genome was assembled using MIRA v. 3.4 [30] and the Roche gsAssembler v. 2.6 to achieve $49 \times$ total genome coverage through the assembly of Roche GS FLX shotgun, GS FLX large insert $(8.3 \mathrm{~kb})$ mate pair, Illumina 75-bp single direction, and Illumina $2 \times 75$ bp paired-end sequencing reads. Some of remaining sequencing gaps in the scaffolded assembly were PCR amplified and sequenced by the Sanger method. GAP5 [31], from the Staden Package, was used as the editor for incorporating the gap-closing sequences, ultimately resulting in a high quality assembly consisting of eight contigs and seven gaps. (The genome start and end points are in a complete contig that was intentionally split to facilitate comparisons to a completed genome of the same genus and species.) Base calling errors in the genome assembly were corrected by using SEQuel [32] to map Illumina reads back to the contigs at approximately $100 \times$ total coverage.

\section{Genome annotation}

The assembled genome was submitted to the National Center for Biotechnology Information (Bethesda, MD) through the Whole Genome Shotgun genome sequencing portal [33] and annotated with the NCBI Prokaryotic Genome Annotation Pipeline. Signal peptides were distinguished from transmembrane regions by using SignalP 4.0 software [34], transmembrane helices were predicted with the method of Krogh et al. [35], and the CRISPR motif was discovered with a web tool described by Griss et al. [36].

\section{Genome properties}

The genome properties and statistics of O. rhinotracheale strain H06-030791 (Accession AXDE00000000) are presented in Tables 3 and 4 and Figure 3. The noncontiguous finished genome consists of a circular $2,319,034$ bp chromosome with a $34.53 \% \mathrm{G}+\mathrm{C}$ content and no plasmids. Of the 2,300 genes predicted, 2,243

Table 4 Number of genes associated with the 25 general COG functional categories of 0 . rhinotracheale strain H06-030791

\begin{tabular}{|c|c|c|c|}
\hline Code & Value & $\%$ age $^{a}$ & Description \\
\hline J & 133 & 5.7 & Translation, ribosomal structure and biogenesis \\
\hline A & 0 & 0 & RNA processing and modification \\
\hline K & 47 & 2.01 & Transcription \\
\hline L & 118 & 5.06 & Replication, recombination and repair \\
\hline B & 0 & 0 & Chromatin structure and dynamics \\
\hline D & 19 & 0.81 & Cell cycle control, cell division, chromosome partitioning \\
\hline Y & 0 & 0 & Nuclear structure \\
\hline V & 36 & 1.54 & Defense mechanisms \\
\hline $\mathrm{T}$ & 24 & 1.03 & Signal transduction mechanisms \\
\hline M & 122 & 5.23 & Cell wall/membrane biogenesis \\
\hline N & 3 & 0.13 & Cell motility \\
\hline Z & 0 & 0 & Cytoskeleton \\
\hline W & 0 & 0 & Extracellular structures \\
\hline$U$ & 27 & 1.16 & Intracellular trafficking and secretion, and vesicular transport \\
\hline O & 66 & 2.83 & Posttranslational modification, protein turnover, chaperones \\
\hline C & 76 & 3.26 & Energy production and conversion \\
\hline G & 78 & 3.34 & Carbohydrate transport and metabolism \\
\hline E & 112 & 4.8 & Amino acid transport and metabolism \\
\hline $\mathrm{F}$ & 52 & 2.23 & Nucleotide transport and metabolism \\
\hline H & 91 & 3.9 & Coenzyme transport and metabolism \\
\hline । & 42 & 1.8 & Lipid transport and metabolism \\
\hline P & 82 & 3.51 & Inorganic ion transport and metabolism \\
\hline Q & 17 & 0.73 & Secondary metabolites biosynthesis, transport and catabolism \\
\hline $\mathrm{R}$ & 150 & 6.43 & General function prediction only \\
\hline S & 89 & 3.81 & Function unknown \\
\hline- & 949 & 40.48 & Not in COGs \\
\hline
\end{tabular}

${ }^{a}$ The total is based on the total number of protein coding genes in the annotated genome. 


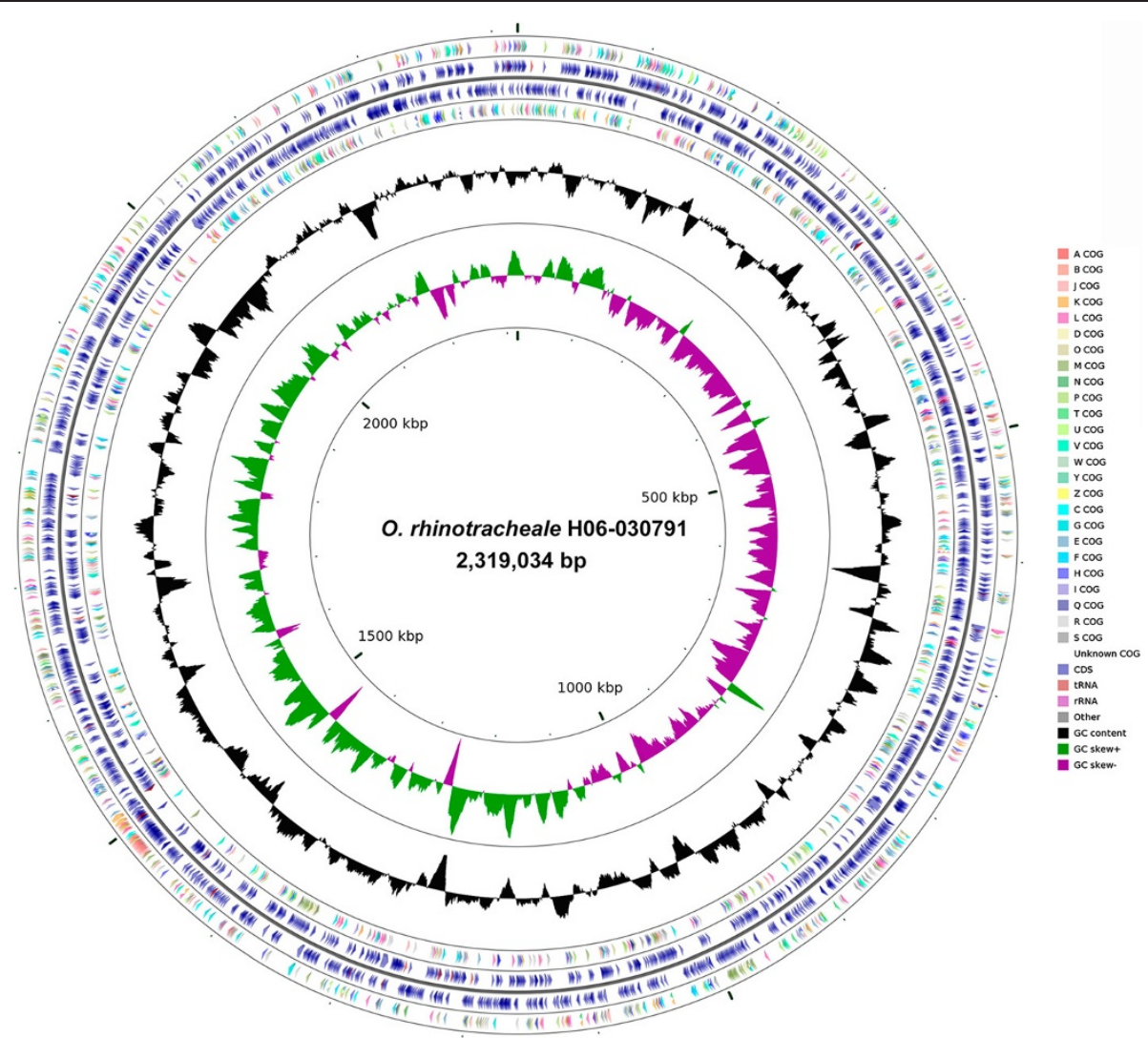

Figure 3 Graphical map of the O. rhinotracheale strain H06-030791 chromosome. From outside to the center: genes on forward strand (color by COG categories), CDS on forward strand, tRNA, rRNA, other; CDS on reverse strand, tRNA, rRNA, other, genes on reverse strand (color by COG categories); GC content; GC skew, where green indicates positive values and magenta indicates negative values.

are protein-coding genes, six are pseudogenes, and nine are RNA genes. The percentage of the protein-coding genes that were assigned a putative function is $47.17 \%$. The distribution of genes into COGs functional categories is presented in Table 4. One CRISPR motif was also detected.

\section{Conclusions}

Prior to this report only a single genome sequence was available for $O$. rhinotracheale, from the type strain LMG 9086, and no corresponding analysis of an O. rhinotracheale genome has been published. Examination of the aligned genomes of these isolates revealed that rearrangements and inversions are the major distinguishing features. Relative to LMG 9086, the genome of H06-030791 contains a single rearrangement of $\sim 31 \mathrm{~Kb}$, a single inversion of $\sim 17 \mathrm{~Kb}$ and three regions that are both inverted and rearranged, varying from $\sim 59-354 \mathrm{~Kb}$ each, many with a transposase or transposon present at one terminus. Thus, mobile elements may play a role in shaping genome structure and evolution of $O$. rhinotracheale. Within one of the inverted and rearranged segments of H06-030791 is an apparent deletion of $\sim 37 \mathrm{~Kb}$ found in LMG 9086, comprised primarily of CDSs annotated as hypothetical proteins but also including a holin family protein, an ATP-dependent serine protease, a helix-turn-helix protein and several phage-related proteins. Owing to gaps in the H06-030791 genome, the putative deletion requires confirmation but it does lie well within the boundaries of the contig in which it is found and adjacent sequences are syntenous with the LMG 9086 genome. Also within the same rearranged/inverted region is an insertion in H06-030791 with five predicted CDSs, four annotated as hypothetical proteins and one as a multidrug $\mathrm{ABC}$ transporter.

Notable phenotypes associated with H06-030791 but not the type strain include $\beta$-hemolytic activity [12] and the ability to grow in the presence of an iron chelator [11]. Only three CDSs whose annotations suggest a function in hemolytic activity were apparent in H06-030791. Identical or nearly identical homologs were found in the LMG 9086 genome. One additional CDS annotated in LMG 9086 as a hemolysin was also found in H06-030791, identical in sequence but annotated there as a glycerol acyltransferase. Among 15 CDSs collectively found in H06-030791 and LMG 9086 whose annotations suggest a 
role in iron acquisition or transport, only one was found to have considerable sequence divergence. The integral membrane protein and ferrous iron transporter FeoB is predicted to be identical in both isolates over the N-terminal 395 amino acids but only $94.7 \%$ identical over the C-terminal 301 amino acids. Motifs found within the divergent region of the protein include a ferrous iron transport protein B C terminus (PF07664.7) flanked by two gate nucleoside recognition domains (PF07670.9). As these are believed to comprise the membrane pore region, sequence heterogeneity may perhaps affect the specificity of transport. Other homologs in H06030791 and LMG 9086 with obvious sequence divergence include several annotated as hypothetical proteins, a transcriptional regulator/sugar kinase with a highly divergent stretch of $\sim 50 \mathrm{bp}$, a Crp/Fnr family transcriptional regulator with nearly all amino acid substitutions in the cyclic nucleotide binding domain (PF00027.24) of the predicted protein and a PAO141 family polyphosphate kinase 2, with substitutions concentrated in the polyphosphate kinase 2 domain (PF03976.9).

The genome sequence of H06-030791, together with those of the type strain and an additional, recently sequenced isolate [38] will provide a framework for future investigations designed to elucidate the genetic basis of virulence in O. rhinotracheale and for understanding genome structure and evolution.

\section{Competing interests}

The authors declare that they have no competing interests.

\section{Authors' contributions}

EZ participated in genome sequencing and drafted the original manuscript. DB directed genome sequence assembly and bioinformatics analyses. WB participated in genome sequencing and post-sequencing analyses. LT conceived of the study and participated in genome sequencing. KR participated in post-sequencing analysis and revised the manuscript. All authors read and approved the final manuscript.

\section{Acknowledgements}

We thank Michael Baker of the lowa State University DNA Facility, Ames, IA and David Alt of the Infectious Bacterial Diseases Research Unit at the National Animal Disease Center, Ames, IA for their DNA sequencing expertise. We thank Linda Cox of the National Veterinary Services Laboratories in Ames, IA for performing the biochemical testing and Judith Stasko and James Fosse of the National Centers for Animal Health, Ames, IA for electron microscopy and image preparation for publication, respectively.

\section{Author details}

${ }^{1}$ Ruminant Diseases and Immunology Research Unit, U. S. Department of Agriculture, Agricultural Research Service, National Animal Disease Center, Ames, IA, USA. ${ }^{2}$ Infectious Bacterial Diseases Research Unit, U. S. Department of Agriculture, Agricultural Research Service, National Animal Disease Center, Ames, IA, USA. ${ }^{3}$ Roy J. Carver Department of Biochemistry, Biophysics and Molecular Biology, lowa State University, Ames, IA, USA.

Received: 5 June 2014 Accepted: 2 October 2014

Published: 8 December 2014

\section{References}

1. Chin RP, Van Empel PCM, Hafez HM. Ornithobacterium rhinotracheale infection. In: Saif YM, editor. Diseases of Poultry. 12th ed. Ames, IA: Blackwell Publishing; 2008: p. 765-74.
2. Charlton BR, Channing-Santiago SE, Bickford AA, Cardona CJ, Chin RP, Cooper GL, Droual R, Jeffrey JS, Meteyer CU, Shivaprasad HL, Walker RL. Preliminary characterization of a pleomorphic gram-negative rod associated with avian respiratory disease. J Vet Diagn Invest. 1993; 5:47-51. PMID: 8466980.

3. Vandamme P, Segers P, Vancanneyt M, Van Hove K, Mutters R, Hommez J, Dewhirst F, Paster B, Kersters K, Falsen E, Devriese LA, Bisgaard M, Hinz K-H, Mannheim W. Ornithobacterium rhinotracheale gen. nov. sp. nov., isolated from the avian respiratory tract. Int J System Bacteriol. 1994; 44(1):24-37. PMID: 8123560.

4. Hafez HM, Vandamme P. Genus XXXIX. Ornithobacterium Vandamme, Segers, Vancanneyt, Van Hove, Mutters, Hommez, Dewhirst, Paster, Kersters, Falsen, Devriese, Bisgaard, Hinz and Mannheim 1994b, $35^{\mathrm{VP}}$. In Krieg NR, Staley JT, Brown DR, Hedlund BP, Paster BJ, Ward NL, Ludwig W, Whitman WB, editors. Bergey's Manual of Systematic Bacteriology, Volume 4. 2nd ed. New York: Springer; 2011: p. 250-4.

5. Hafez HM, Lierz M. Ornithobacterium rhinotracheale in nestling falcons. Avian Dis. 2010; 54(1):161-3. PMID: 20408418.

6. van Veen L, Gruys E, Frik K, van Empel P. Increased condemnation of broilers associated with Ornithobacterium rhinotracheale. Vet Rec. 2000; 147(15):422-3. doi:10.1136/vr.147.15.422.

7. Sprenger SJ, Halvorson DA, Nagaraja KV, Spasojevic R, Dutton RS, Shaw DP. Ornithobacterium rhinotracheale infection in commercial laying-type chickens. Avian Dis. 2000; 44(3):725-9. PMID: 11007028

8. De Rosa M, Droual R, Chin RP, Shivaprasad HL, Walker RL. Ornithobacterium rhinotracheale infection in turkey breeders. Avian Dis. 1996; 40(4):865-74. doi:10.2307/1592311.

9. van Empel PCM, Hafez HM. Ornithobacterium rhinotracheale: a review. Avian Pathol. 1999; 28(3):217-27. doi:10.1080/03079459994704.

10. Schuijffel DF, van Empel PCM, Segers RPAM, Van Putten JPM, Nuijten PJM. Vaccine potential of recombinant Ornithobacterium rhinotracheale antigens. Vaccine. 2006; 24:1858-67. doi:10.1016/j.vaccine.2005.10.031.

11. Tabatabai LB, Zehr ES, Zimmerli MK, Nagaraja KV. Iron acquisition by Ornithobacterium rhinotracheale. Avian Dis. 2008; 52(3):419-25. PMID: 18939629.

12. Tabatabai LB, Zimmerli MK, Zehr ES, Briggs RE, Tatum FM. Ornithobacterium rhinotracheale North American field isolates express a hemolysin-like protein. Avian Dis. 2010; 54(3):994-1001. PMID: 20945779.

13. Ludwig W, Euzéby J, Whitman WB. Taxonomic outlines of the phyla Bacteroidetes, Spirochaetes, Tenericutes (Mollicutes), Acidobacteria, Fibrobacteres, Fusobacteria, Dictyoglomi, Gemmatimonadetes, Lentisphaerae, Verrucomicrobia, Chlamydiae, and Planctomycetes. In: Krieg NR, Staley JT, Brown DR, Hedlund BP, Paster BJ, Ward NL, Ludwig W, Whitman WB, editors. Bergey's Manual of Systematic Bacteriology, Volume 4. 2nd ed. New York: Springer; 2011: p. 21-2.

14. Field D, Garrity G, Gray T, Morrison N, Selengut J, Sterk P, Tatusova T, Thomson N, Allen MJ, Angiuoli SV, Ashburner M, Axelrod N, Baldauf S, Ballard S, Boore J, Cochrane G, Cole J, Dawyndt P, De Vos P, dePamphilis C, Edwards R, Faruque N, Feldman R, Gilbert J, Gilna P, Glöckner FO, Goldstein $P$, Guralnick R, Haft D, Hancock D, et al. The minimum information about a genome sequence (MIGS) specification. Nat Biotechnol. 2008; 26(5):541-7. doi:10.1038/nbt1360.

15. Nomenclature Abstract for "Bacteria". The NamesforLife Abstracts. Garrity GM, Parker CT, Ed. 2013 NamesforLife, LLC; http://doi.org/10.1601/nm.419.

16. Woese $C R$, Kandler $O$, Wheelis ML. Towards a natural system of organisms: proposal for the domains Archaea, Bacteria, and Eucarya. Proc Natl Acad Sci U S A. 1990; 87:4576-9.

17. Nomenclature Abstract for "Bacteroidetes". The Namesforlife Abstracts. Garrity GM, Parker CT, Ed. 2013 NamesforLife, LLC; http://doi.org/10.1601/nm.7927.

18. Garrity GM, Lilburn TG, Cole JR, Harrison SH, Euzéby J, Tindall BJ. Taxonomic outline of the Bacteria and Archaea, Release 7.7 March 6, 2007; Part 1 The "Archea", Phyla "Crenarchaeota" and "Euryarchaeota". Taxonomic Outline. 2007:551-73. doi:10.1601/TOBA7.7.

19. Nomenclature Abstract for "Flavobacteriia". The Namesforlife Abstracts. Garrity GM, Parker CT, Ed. 2014 NamesforLife, LLC; http:/doi.namesforlife.com/10.1601/nm.22978.

20. Bernardet J-F. Class II. Flavobacteriia class. nov. In: Krieg NR, Staley JT, Brown DR, Hedlund BP, Paster BJ, Ward NL, Ludwig W, Whitman WB, editors. Bergey's Manual of Systematic Bacteriology. 2nd ed. Volume 4. New York: Springer; 2011: p. 105.

21. Nomenclature Abstract for Flavobacteriales. The NamesforLife Abstracts. Garrity GM, Parker CT, (Eds). 2012 NamesforLife, LLC; http://doi.org/10.1601/nm.8069.

22. Bernardet J-F. Order I. Flavobacteriales ord. nov. In: Krieg NR, Staley JT, Brown DR, Hedlund BP, Paster BJ, Ward NL, Ludwig W, Whitman WB, editors. Bergey's Manual of Systematic Bacteriology. 2nd ed. New York: Springer; 2011: p. 105. 
23. Nomenclature Abstract for Flavobacteriaceae. The Namesforlife Abstracts. Garrity GM, Parker CT, Ed. 2014 NamesforLife, LLC; http://doi.org/10.1601/nm.8070

24. Reichenbach H. Order 1. Cytophagales Leadbetter 1974, 99A. In: Holt JG, editor. Bergey's Manual of Systematic Bacteriology. 1st ed. Volume 3. Baltimore, MD: The Williams and Wilkins Co; 1989: p. 2011-3.

25. Bernardet JF, Nakagawa Y, Holmes B. Proposed minimal standards for describing new taxa of the family Flavobacteriaceae, and emended description of the family. Int I Syst Evol Microbiol. 2002; 52:1049-70. doi:10.1099/ijs. 0.02136-0.

26. Nomenclature Abstract for Ornithobacterium. The Namesforlife Abstracts. Garrity GM, Parker CT, Ed. 2009 NamesforLife, LLC; http://doi.org/10.1601/ nm.8175.

27. Vandamme $P$, Segers $P$, Vancanneyt $M$, van Hove $K$, Mutters $R$, Hommez J, Dewhirst F, Paster B, Kersters K, Falsen E, Devriese LA, Bisgaard M, Hinz K-H, Mannheim W. Ornithobacterium rhinotracheale gen. nov., sp. nov., isolated from the avian respiratory tract. Int J Syst Bacteriol. 1994; 44:24-37. doi:10.1099/00207713-44-1-24.

28. BAuA) GFIfOSaH. 2010 Classification of prokaryotes (bacteria and archaea) into risk groups, technical rules for biological agents (TRBA) 466:159. Bundesanstalt für Arbeitsshutz und Arbeitsmedizin (BAuA. http://www.baua.de/de/Startseite.html.

29. Ashburner M, Ball CA, Blake JA, Botstein D, Butler H, Cherry JM, Davis AP, Dolinski K, Dwight SS, Eppig JT, Harris MA, Hill DP, Issel-Tarver L, Kasarskis A, Lewis S, Matese JC, Richardson JE, Ringwald M, Rubin GM, Sherlock G. Gene ontology: tool for the unification of biology. Nat Biotechnol. 2000; 25(1):25-9. doi:10.1038/75556.

30. Chevreux B, Wetter T, Suhai S. Genome sequence assembly using trace signals and additional sequence information. Comp. Sci. Biol.: Proc. German Conference on Bioinformatics GCB '99 (GCB) 1999; 99:45-56. http:// www.bioinfo.de/isb/gcb99/talks/chevreux/.

31. Bonfield JK, Whitwham A. Gap5-editing the billion fragment sequence assemby. Bioinformatics. 2010; 26(14):1699-703. doi:10.1093/bioinformatics/ btq268.

32. Ronen R, Boucher C, Chitsaz H, Pevzner P. SEQuel: improving the accuracy of genome assemblies. Bioinformatics. 2012; 28(12):i188-96. doi:10.1093/bioinformatics/bts219.

33. portal NWGSWgsp. https://submit.ncbi.nlm.nih.gov/subs/wgs/.

34. Petersen TN, Brunak S, von Heijne G, Nielsen H. SignalP 4.0: discriminating signal peptides from transmembrane regions. Nat Methods. 2011; 8(10):785-6. doi:10.1038/nmeth.1701.

35. Krogh A, Larson B, von Heijne G, Sonnhammer ELL. Predicting transmembrane protein topology with a hidden Markov model: Application to complete genomes. J Mol Biol. 2001; 305(3):567-80. doi:10.1006/jmbi.2000.4315.

36. Grissa I, Vergnaud G, Pourcel C. CRISPRFinder: a web tool to identify clustered regularly interspaced short palindromic repeats. Nucleic Acids Res. 2007; 35:W52-7. doi:10.1093/nar/gkm360.

37. Tamura K, Peterson D, Peterson N, Stecher G, Nei M, Kumar S. MEGA5: Molecular evolutionary genetics analysis using maximum likelihood, evolutionary distance, and maximum parsimony methods. Mol Biol Evol. 2011; 28(10):2731-9. doi:10.1093/molbev/msr121.

38. Zehr ES, Bayles DO, Boatwright WD, Tabatabai LB, Register KB. Complete genome sequence of Ornithobacterium rhinotracheale strain ORT-UMN 88. Stand. Genomic Sci. 2014; 9:16. doi:10.1186/1944-3277-9-16

\section{Submit your next manuscript to BioMed Central and take full advantage of:}

- Convenient online submission

- Thorough peer review

- No space constraints or color figure charges

- Immediate publication on acceptance

- Inclusion in PubMed, CAS, Scopus and Google Scholar

- Research which is freely available for redistribution

Submit your manuscript at www.biomedcentral.com/submit 